\title{
2. \\ RAZVOJNI PUTEVI JEZIKA: \\ OD NACRTA DO SUVREMENOG \\ KNJIŽEVNOJEZIČNOG IZRAZA
}

\section{Virna Karlić}

UDK: 801.163.41’26“191/195“

Izvorni znanstveni članak

Sažetak: U radu se raspravlja o razvojnim procesima suvremenog književnojezičnog izraza koji su se odvili krajem 19. te tijekom prve polovine 20. stoljeća. Riječ je o razdoblju u kojem je prethodno dogovoreni i formalno prihvaćeni nacrt književnog jezika počeo oživljavati, razvijati se i bogatiti u djelima pisaca, publicista, znanstvenika, prevoditelja i drugih kulturnih radnika u urbanim centrima poput Beograda, Novog Sada i Zagreba. Nakon kratkog prikaza općih razvojnih, standardizacijskih faza književnog jezika, fokus se usmjerava na književno-jezični kontekst u kojem su stvarali srpski (prvenstveno beogradski) pisci prve polovine 20. stoljeća. Ukazuje se na ulogu njihova stvaralaštva u procesu razvoja suvremenog srpskog književnog jezika te se raspravlja o pojmu beogradski stil, kojim se obilježava taj prijelomni period njegove standardizacije. Na koncu se prikazuju konkretne jezične inovacije koje je beogradski stil donio u odnosu na vukovski jezik.

Ključne riječi: povijest jezika, književni jezik, standardizacija, srpski jezik, beogradski stil, hrvatski jezik

\section{UVOD}

? ? vid u kroatističke i srbističke sintetičke povijesne preglede razvoja književnog jezika otkriva jedno njihovo zajedničko obilježje - usredotočenost na 19. stoljeće kao razdoblje u kojem se odvila njegova standardizacija. U to su vrijeme doista donesene neke presudne odluke o njegovoj osnovici (faza selekcije i opisa) i eksplicitnoj normi (faza propisivanja). Međutim, razvojni put književnog jezika podrazumijeva mnogo više od tih triju faza.

U središtu interesa ovog rada jest proces koji se počeo odvijati u trenutku kada je dogovoreni i formalno prihvaćeni nacrt književnog jezika počeo oživljavati, razvijati se i bogatiti u djelima pisaca, publicista, znanstvenika, prevoditelja i drugih kulturnih radnika koji su djelovali prvenstveno u urbanim centrima poput Beograda, Novog Sada i Zagreba krajem 19. i početkom 20. stoljeća. U tom su razdoblju nastali takozvani beogradski stil i zagrebački stil ${ }^{1}$,

$\overline{1}$ Termin beogradski stil u stručnoj je literaturi znatno zastupljeniji od termina zagrebački stil, kojim se služe tek pojedini autori (npr. Petar Skok). Što se tiče naziva beogradski stil, on se najčešće zbog svojih nedostataka koristi pod navodnim 
u okviru čijeg se razvoja odvijaju ključni koraci prema uspostavljanju suvremenog književnog jezika kao organizma kojem su život (na temelju prethodno uspostavljenog nacrta) podarili pisci kroz svoje sve raznolikije i raslojenije književno-umjetničko, znanstveno, publicističko i svako drugo stvaralaštvo.

S obzirom na to da su ovogodišnji Desničini susreti održani u Beogradu, u radu je posebna pažnja posvećena književno-jezičnom kontekstu u kojem su srpski (prvenstveno beogradski) pisci prve polovine 20. stoljeća stvarali, kao i na ulogu njihova stvaralaštva u procesu razvoja suvremenog književnog jezika.

\section{RaZvojni PUTEVi KNJIŽEVNOG JEZIKA}

Svaki književni jezik ima svoj specifičan razvojni put. Upravo se zbog toga pojedini književni jezici razlikuju mnogim svojim obilježjima - po organskoj osnovici na kojoj su nastali, stupnju autonomnosti (u odnosu na druge jezike i vlastite nestandardne varijetete), stupnju normiranosti, funkcijama koje vrše, (dis)kontinuiranosti razvoja te broju govornika i naroda koji se njima služe. ${ }^{2}$ Unatoč svim tim razlikama, njihov se razvojni, standardizacijski proces može svesti na nekoliko univerzalnih faza, koje se ne moraju nužno odviti sukcesivno i zadanim redoslijedom. ${ }^{3}$ Osim toga, svaka od tih faza specifična je za pojedini jezik - kako zbog jezičnih, tako i zbog izvanjezičnih, prvenstveno sociopolitičkih i kulturnih čimbenika.

Kada je riječ o suvremenom srpskom književnom jeziku, počeci procesa standardizacije javljaju se na prijelazu iz 18. u 19. stoljeće. U to se vrijeme zahuktava rasprava o selekciji njegove osnovice nakon dugog perioda „otvorenog jezičnog pitanja“, u kojem je nekoliko različitih idioma usporedno vršilo funkciju književnog jezika: ruskoslavenski, slavenosrpski, ruski i srpski narodni jezik. ${ }^{4}$ Budući da se takva višejezičnost pokazala neodrživom, nakon dugotrajnih i burnih rasprava među predstavnicima različitih uvjerenja i usmjerenja, prevladala je struja - na čelu s Vukom Stefanovićem Karadžićem - koja se zalagala za narodni jezik kao osnovicu književnojezičnog izraza. Time je uslijedio prekid s dotadašnjom viševjekovnom staroslavenskom jezičnokulturnom tradicijom, čime je $s$ jedne strane uspostavljen diskontinuitet književnojezičnog i kulturnog razvoja, dok su s druge strane postavljeni temelji novog i drugačijeg kontinuiteta.

znacima. Naime, njegovu je uvođenju najviše pridonijela Isidora Sekulić, koja je smatrala da je riječ o stilskoj vještini, a ne o novijem obliku vukovskog književnog jezika koji se razvio u beogradskoj sredini (usp. Александар БЕцић, „Београаски сти “, Наш језик, 2/1934., br. 7, 193-200), odnosno o jednom od „prijelomnih perioda u razvoju srpskog standardnog jezika“ (ВАадо ЂукАновић, „Београдски стил - премомни период у развоју српског стандарАног језика“, Наш језик, 30/1995., br. 1-5, 122-131).

3 Broj faza standardizacije razlikuje se od teorije do teorije. U ovom se radu polazi od Radovanovićeva desetofaznog modela (Isto).

4 Riječ je o drugoj polovini 18. stoljeća. Nakon što je tridesetih godina 18. stoljeća funkciju književnog jezika preuzeo ruskoslavenski, među piscima „svjetovnjacima“ spontano se počinje razvijati slavenosrpski jezik - nikada ujednačen/ normiran hibridni jezik nastao miješanjem prije svega ruskoslavenskog i srpskog narodnog jezika, uz elemente srpskoslavenskog i ruskog književnog jezika. Uz ruskoslavenski i slavenosrpski jezik, u to je vrijeme funkciju književnog jezika parcijalno vršio i ruski književni jezik, dok krajem 18. stoljeća sve više jača afirmacija, a ujedno i upotreba narodnog jezika u toj ulozi. 
Kao organsku osnovicu književnog jezika Vuk Stefanović Karadžić odredio je istočnohercegovački dijalekt, koji su on i njegovi sljedbenici (pr)opisali na gramatičkoj (prvenstveno morfološkoj i tvorbenoj) i leksičkoj razini. Time su načelno zaključena naredna dva procesa standardizacije - opis organske osnovice književnog jezika i njegova kodifikacija. Valja, međutim, naglasiti da je kodifikacija umnogome bila tek simbolična s obzirom na to da se tijekom 19. stoljeća norma uglavnom prihvaćala podržavanjem praktičnih modela i gotovih obrazaca ${ }^{5}$ te još uvijek nije iskristalizirana granica između narodnog i književnog jezika. ${ }^{6}$ Osim toga, nadolazeći razvojni putevi književnog jezika donijeli su brojne i značajne inovacije u odnosu na vukovski jezik, stoga je važno istaknuti da je u tom razdoblju proces kodifikacije tek započet, a zaključen je naknadno, tijekom 20. stoljeća.

Poznato je da Karadžićev prijedlog jezične i azbučne reforme među Srbima nije glatko prihvaćen te je prošlo pola stoljeća do njegova punog prihvaćanja. ${ }^{7}$ Procesi akceptuacije (službenog prihvaćanja norme) i implementacije (stvarnog ulaska norme u upotrebu) odvili su se odvojeno. Iako su se i prije službenog prihvaćanja Karadžićeve jezične reforme pisala i objavljivala djela na vukovskom jeziku, o njegovoj se široj upotrebi može govoriti tek u nadolazećim periodima.

Proces ekspanzije (teritorijalno i socijalno širenje upotrebe književnog jezika) nije završen sve do današnjih dana, ${ }^{8}$ a u vrijeme kada je Karadžićeva jezična reforma formalno prihvaćena, postotak pismenog stanovništva iznosio je svega 4,7\%. ${ }^{9}$

Proces ekspanzije književnog jezika usko je povezan s procesom kultivacije, koji podrazumijeva brigu za jezik te njegovo propagiranje u okviru školstva, izdavačke aktivnosti, masovnih medija i institucija zaduženih za taj zadatak. Ovaj je proces izravno navezan na proces urbanizacije te povećanje fizičke i socijalne pokretljivosti stanovništva, a nije ga moguće provesti bez razrađene infrastrukture i sustavno provođenog jezičnog planiranja.

Budući da bi književni jezik po svojoj definiciji trebao zadovoljavati sve funkcije koje nalaže suvremeno društvo te biti prilagodljiv aktualnim društvenim promjenama, proces njegove standardizacije u principu nikada ne završava te se stoga njegova norma kontinuirano evaluira i po potrebi rekonstruira.

S obzirom na organsku osnovicu koja je na samom početku ovog procesa izabrana kao baza suvremenog srpskog književnog jezika, najkompleksniji i najizazovniji razvojni proces njegove standardizacije zasigurno je bila elaboracija. Ona podrazumijeva razvoj i razradu prethodno izabrane, opisane i propisane organske osnovice u svrhu strukturnog i funkcionalnog osposobljavanja te prilagodbe jezika složenim i promjenjivim društvenim i kulturnim, komunikacijskim i stvaralačkim potrebama.

\footnotetext{
В. БукАновић, „БеограАски стик“, 125.

6 Павле Ивит, Преглед историје српског језика, Сремски Кармовци - Нови СаА 1988., 261.

7 Godine 1818. izlazi prvo izdanje Karadžićeva Rječnika u kojem autor izlaže temeljne postavke svoje reforme. Tek 1868. godine njegova reforma u cijelosti biva formalno odobrena i prihvaćena.

8 To potvrđuju brojke s posljednjeg popisa stanovništva iz 2012. godine, kada je zabilježeno oko 165.000 potpuno nepismenih stanovnika Srbije, među kojima udio od čak $80 \%$ čine žene. Pritom čak $14 \%$ populacije Srbije (677.000 stanovnika) nema osnovno obrazovanje. Navedeni podaci preuzeti su sa službene mrežne stranice Republičkog zavoda za statistiku RS (http://webrzs.stat.gov.rs).

9 В. ЂукАновић, „Београдски стик“, 126.
} 
U nastavku rada promatra se ključna faza elaboracije suvremenog srpskog književnog jezika - faza u kojoj se vukovski književni jezik počinje raslojavati po uzoru na raslojenost pripadajuće kulture i društva, što je u konačnici dovelo do razvoja brojnih funkcionalnih stilova. Drugim riječima, pokušat će se u kratkim crtama prikazati kako je tekao razvojni put jezika od vukovskog nacrta do suvremenog književnojezičnog izraza.

\section{OsNOVICA KNJIŽEVNOG JEZIKA}

Književni jezici mogu se razviti nadogradnjom različitih tipova organskih osnovica. Primjerice, mnogi se književni jezici zasnivaju na varijetetu glavnoga grada kao kulturnog centra, na nekom drugom jezičnom varijetetu (dijalektu/sociolektu) ili jeziku osvajača, odnosno kolonizatora.

Izbor i prihvaćanje istočnohercegovačkog dijalekta kao osnovice književnog jezika (koja iza sebe ne posjeduje pisanu književnojezičnu tradiciju) te zagovaranje modela književnog jezika koji izravno odražava način na koji narod govori, imao je pozitivne i negativne efekte na pojedine procese njegove standardizacije. Na primjer, izbor je takve osnovice bez sumnje olakšao i ubrzao njegovu implementaciju i širenje. Međutim, suočavanje s problemima u sklopu faze elaboracije književnog jezika, koja podrazumijeva njegov razvoj i prilagodbu svim funkcijama društvene i državne zajednice, pokazalo se izuzetno izazovnim:

Vukov književni jezik, budući da potiče iz tradicionalne usmene ruralne kulture, a preuzimajući komunikacionu ulogu u novoj urbanoj kulturi i pisanoj književnosti, prošao je kroz proces „složenog i mučnog preslagivanja novim potrebama“, tako da se tek sa „beogradskim stilom" početkom 20 . veka konstituiše moderan književni jezik. ${ }^{10}$

Uzrok „složenosti i mučnosti“ toga preslagivanja leži prije svega u funkcionalnoj ograničenosti izabrane organske osnovice, koja je odražavala način na koji su živjeli njezini izvorni govornici - nepismen, neobrazovan narod.

Narod je stvarao reči samo za ono za što su mu one trebale; za ono što nije poznavao, on ne samo da nije stvarao reči, nego nema u svojem rečniku ni osnova iz kojih bi se one mogle u duhu jezika izvesti. ${ }^{11}$

Vukovski jezik nastao je isključivo na usmenim obrascima, međutim vrlo je brzo stvorena svijest o važnosti razvoja njegove pisane realizacije i funkcionalne raslojenosti te stabilizacije njegove norme i upotrebe. Potreba za tim instancijama rezultirala je nemalim odstupanjima u odnosu na izvorne Karadžićeve zamisli. Što se tiče same organske osnovice, Karadžićeva prvobitna ideja da u osnovu književnog jezika uđe samo istočnohercegovački dijalekt $s$ vremenom se modificirala proširivanjem osnovice na šumadijsko-vojvođanski dijalekt, čemu je bitno pridonijela „strateška bliskost govora koji čine policentričnu osnovicu standardnog jezika“:

10 Весна МАтовић, „Писци као творци српског књижевног језика“, Зборник Твории српског књижевног језика (ур. Весна Матовић и Миодраг Матицки), Београд 2011., 11; Новица пЕтковић, „Језик, књижевност и култура“, Словенске пчеле у Грачаниии, Београд 2007., 30.

11 Һубомир НЕАит, „Српски књижевни језик“, Сабрана дела, Београд 1929., 245. 
Do sredine 19. veka tadašnji kulturni jezik već se u dobroj meri približio svom supstratnom šumadijsko-vojvođanskom dijalektu (tj. bitno ga je apsorbovao) i ta je činjenica suštinski omela formiranje norme isključivo na supstratu istočnohercegovačkog dijalekta. ${ }^{12}$

Dakle, iako se prednost davala istočnohercegovačkom supstratu, vrlo se brzo utjecaj glavnih kulturnih središta (prvenstveno Beograda i Novog Sada) pokazao presudnim, a sve veće uvažavanje teritorijalnog raslojavanja srpskog jezika uočljivo je već u Karadžićevu Srpskom rječniku iz 1852. godine.

Iako je u sklopu Karadžićeve Male srbske pismenice (1814.) i Rječnika (1818., 1852.) te Daničićeve Male srpske gramatike (1850.) u velikoj mjeri utvrđena grafijska, fonološka, morfološka i tvorbena norma vukovskog književnog jezika, valja naglasiti da to ni približno nije bio slučaj na sintaktičkoj, leksičkoj i stilskoj/stilističkoj razini. ${ }^{13}$ Opsežan i iznimno kompleksan proces razvoja, a potom i normiranja jezika na tim razinama uslijedio je tek krajem 19. i u prvim desetljećima 20. stoljeća, kada su za to stečeni društveni, politički, kulturni i ekonomski uvjeti. Izostanak pisane tradicije na narodnom jeziku te podržavanje principa piši kako narod govori odražavao se na nekoliko ravni: u nerazvijenoj i neustaljenoj sintaksi pisanoga diskursa, siromašnom leksičkom fondu te funkcionalnoj neraslojenosti jezika. Svi su ti nedostaci u podjednakoj mjeri onemogućavali da tadašnji vukovski jezik ispunjava sve uloge i funkcije koje mu je onovremeno društvo nalagalo.

Ovdje se nameće ključno pitanje o tome kako je takav nacrt književnog jezika prerastao u zreo, stabilan, bogat, kreativan, raznolik i produktivan književnojezični izraz kakav nalazimo u djelima pisaca, publicista, novinara, znanstvenika i drugih kulturnih radnika već početkom 20. stoljeća. To „prerastanje“ svojim obilježjima odgovara procesu elaboracije, koji se u ovom slučaju odvio izuzetnom brzinom i intenzitetom. Taj se proces u historiografiji srpskog književnog jezika naziva beogradskim stilom, koji filolozi definiraju kao početnu, a ujedno i prijelomnu fazu razvoja suvremenog srpskog književnog jezika.

\section{ElaboraciJa KNJIŽEVNOG JEZIKA - BEOGRADSKI STIL}

Nakon službenog prihvaćanja cjelokupne azbučne i jezične reforme Vuka Stefanovića Karadžića, 1868. godine nastupa razdoblje brzog i neometanog razvoja srpskog književnog jezika.

Temelji tog jezika bili su čvrsto postavljeni u prethodnom periodu (...) i na dnevnom redu je ostajalo uobličavanje i popunjavanje upravo u onim oblastima u kojima se razvijen jezik najviše razlikuje od siromašnog - u rečniku i sintaksi. ${ }^{14}$

12 В. ЂукАновић, „Београдски стик“, 125.

13 Prema Đukanoviću (isto, 125), u najznačajnijim gramatičkim opisima vukovskog jezika iz 19. stoljeća (Mala srpska gramatika Đure Daničića iz 1950. godine; Srpska gramatika Stojana Novakovića iz 1894. godine te Maretićeva Gramatika i stilistika hrvatskoga ili srpskoga književnog jezika iz 1899. godine) nema kodifikacije jer se norma utvrđuje prihvaćanjem implicitnih obrazaca istočnohercegovačkog dijalekta.

14 П. Ивић, Преглед историје сриског језика, 256. 
Takav slijed događaja bio je rezultat društvenih, političkih i ekonomskih promjena koje nastupaju krajem 19. i početkom 20 stoljeća - posebice u velikim gradovima u koje se slijevaju srpski intelektualci. ${ }^{15}$

Daljnji putevi jezičnog razvoja bili su određeni i potaknuti prvenstveno razvojem prosvjete i kulture, a time i sve većim brojem autora koji pišu (šireći svojim djelovanjem izražajne mogućnosti jezika), kao i njihovih čitatelja. Osim toga, u kulturnim centrima nastupaju brojne promjene i inovacije: pojavljuju se nove struke te se razvijaju novinarstvo i znanost. Sve te društvene promjene izvršile su direktan utjecaj na jezik. Budući da se prethodno zagovarani narodni jezik pokazao neadekvatnim za potrebe društva u kulturnim centrima na prijelazu iz 19. u 20. stoljeće, nastupa novi obrat u vidu udaljavanja od njegove usmene, folklorne osnovice.

Beogradski stil, kao početna faza savremenog srpskog jezičkog standarda, začeo se u urbanoj generaciji koja je u znatno većoj meri nego dotadašnje pohodila školu, u generaciji intelektualaca koji su se u znatnom broju školovali u inostranstvu i koji su se u tom smislu suštinski odvojili od slabije artikulisane mitologizovane apstrakcije Naroda (koju je simbolizovao nepismeni seljak) i okrenuli se jače artikulisanoj, ali takođe mitologizovanoj, apstrakciji Nacije (koju simbolizuje pismeni građanin). ${ }^{16}$

Utoliko beogradski stil označava pomak od ruralnog prema urbanom te konačan prekid s narodnim jezikom kao dominantnim standardnojezičnim modelom. Time Beograd postaje „standardnojezički melting pot ${ }^{\text {“17 }}$ - grad u kojem su koncentrirane pismenost, znanost, kultura i državna administracija; grad čiji stanovnici s vremenom počinju govoriti i pisati ujednačenim jezikom. „Jezik se, dakle, udaljio od svoje folklorne osnove, koja ga je u velikoj meri i sputavala, ali je ostao narodni, mada oplemenjen uticajem evropske kulture. "18

Ovakav slijed događaja rezultirao je značajnim udaljavanjem od ideja za koje se Vuk Stefanović Karadžić prvobitno zalagao. ${ }^{19}$ Došlo je do modifikacije samog supstrata književnog jezika, napuštanja temeljnog vukovskog principa piši kako narod govori, uvođenja kompromisnog rješenja o ravnopravnom odnosu ijekavice i ekavice te brojnih drugih inovacija, razrada i nadgradnji u odnosu na izvorno zamišljen vukovski jezik. Unatoč svim tim promjenama, i danas u temeljima suvremenog srpskog književnog jezika neosporno stoji Karadžićevo opredjeljenje za narodni jezik. Ipak, ključne etape sazrijevanja književnojezičnog izraza odvile su se nakon njegove smrti - krajem 19. i tijekom 20. stoljeća (od redefiniranja osnovice, propisivanja norme na svim jezičnim razinama, horizontalnog i vertikalnog širenja upotrebe, kultivacije i kontinuirane elaboracije). Iz tog razloga mnogi stručnjaci dijele stav da je beogradski stil ključan period razvoja srpskog književnog jezika:

[Beogradski stil je] jedan od prelomnih perioda u razvoju savremenog standardnog jezika. U tom periodu prestaje podražavanje „vukovskog stila“ i počinje podražavanje „beogradskog

\footnotetext{
15 Александар Мимановић, Кратка историја српског жњижевног језика, Београд 2006., 136.

16 В. ЂУкАновић, „Београдски стик“, 129.

17 Isto.

18 А. МимАновић, Кратка историја српског къижевног језика, 136.

19 On je i sâm s vremenom mijenjao neke svoje ključne stavove o književnom jeziku. Tako se, primjerice, na početku zalagao za ideju da svaki pisac treba pisati jezikom svojega kraja, no s vremenom je napušta.
} 
stila“, što će u konačnom ishodu, tridesetih godina 20. veka, dovesti do stabilizovanja sintaktičke norme i do stvaranja temelja za savremenu i potpunu kodifikaciju norme. ${ }^{20}$

Unatoč tome, u svim sintetičkim opisima standardizacije srpskog jezika fokus je usmjeren na 19. stoljeće, dok na pitanje o njegovu razvoju u tom ključnom periodu - kada počinje živjeti i razvijati se u djelima pisaca, znanstvenika, novinara i drugih kulturnih radnika - još uvijek nije ponuđen cjelovit, precizan i, u konačnici, uvjerljiv odgovor. A taj odgovor, dakako, leži u njihovim djelima.

\section{Pisci kao (su)tvorci knjižEvNog Jezika}

Nije dosta samo jedno usvojeno narječje za formaciju kulturnoga književnoga jezika, koji je kulturna pojava par excellence, već su potrebni i veliki opće poznati pisci koji tom opće usvojenom narječju daju umjetnički život, klasični izražaj. Izraz se velikih pisaca zbog svoje klasičnosti imitira i u daljim tvorevinama tako iživljava, da se može stvoriti određeni pravac u razvitku književnoga jezika. ${ }^{21}$

Na pitanje tko su tvorci beogradskog stila Aleksandar Belić odgovara da bi to bili „svi oni koji su u duhu Vukovu do danas pisali u Beogradu ili u njegovu književnom području“, dodavši pritom kako je taj odgovor „suviše opšte prirode“, ali da je „u njemu ipak veliki deo istine“22. Prema Pavlu Iviću, prvoj generaciji utemeljitelja beogradskog stila pripadaju prozni pisci realisti, počevši s autorima seoske pripovijetke - Milovanom Glišićem, Milanom Đ. Miličevićem i Jankom Veselinovićem. „Zajedno sa seoskim temama oni su uneli i seoski jezik, potpuno u skladu i sa vukovskom orijentacijom u srpskoj kulturi i sa načelom realizma u književnosti. “ ${ }^{23}$ Budući da su sva trojica podrijetlom bila iz krajeva u kojima se dijalekt ne razlikuje bitno od ekavske varijante vukovskog jezika, u tom razdoblju još uvijek nije definirana jasna granica između narodnog i književnog jezika. Prvi autor koji je u svoja djela uveo gradski govor bio je Laza Lazarević, a uz njega se kao pripadnici prve generacije beogradskog stila spominju i Svetolik Ranković, Stevan Sremac i Simo Matavulj.

Među pjesnicima iz razdoblja realizma i moderne koji su utemeljili beogradski stil posebno se ističu Vojislav Ilić te modernisti pod utjecajem francuske poezije (Jovan Dučić, Milan Rakić, Vladislav Petković Dis, Milutin Bojić) koji su „(...) oslobodili jezik srpske poezije za izražavanje modernog senzibiliteta ${ }^{\text {“24. }}$.

Jedna od presudnih odlika svakog razvijenog književnog jezika jest njegova polifunkcionalnost. Za stilsko raslojavanje književnog jezika (posebice njegova znanstvenog i publicističkog stila) u tom su razdoblju najzaslužniji bili: književni kritičar i esejist Bogdan Popović, književni povjesničar i kritičar Jovan Skerlić, povjesničar književnosti Pavle Popović te

20 В. ЂУкАновић, „Београдски стим“, 131.

21 Petar Sкок, „O jezičnoj kulturi“, Jezik, 1/1952., br. 1-2, 8.

22 А. БЕцић, „БеограАски стик“, 193.

23 П. Ивић, Преглед историје српског језика, 260.

24 Isto. 
pravnik, sociolog i povjesničar Sobodan Jovanović. Oni su zajedno sa spomenutim piscima bili presudne figure u procesu utemeljivanja i razvoja beogradskog stila.

Zahvaljujući ovoj skupini autora koji su živjeli i stvarali krajem 19. i početkom 20. stoljeća, razvio se jezik proširenih izražajnih mogućnosti, bogatijeg leksika, stabilnije gramatičke norme, stilski i funkcionalno raslojeniji, sintaktički razvijeniji, urbaniji, po potrebi intelektualniji i prilagođeniji potrebama tadašnjeg društva u odnosu na vukovski jezik. Posebno je važno naglasiti da se u to vrijeme jezična norma stabilizirala te da je nakon prve generacije utemeljitelja beogradskog stila „Beograd već bio počeo svojim velikim valjkom da uravnjava i stvara staze po kojima se moglo lako i udobno ići“"25.

Unatoč brojnim značajnim promjenama, srpski (kao i hrvatski) književni jezik u 20. stoljeću umnogome ostaje na tragu temeljnih vukovskih ideja. Međutim, mijenjaju se neka temeljna načela: „Današnji naš književni jezik ne poklapa se više s određenim narječjem. Dobio je pečat u književnom izražaju Zagreba odnosno Beograda i ne može se više kao pravilo postavljati: Piši onako, kako narod govori, nego Piši onako, kako dobri pisci pišu." ${ }^{26}$

Već je prethodno spomenuto da proces standardizacije književnog jezika nikada ne završava. U tom smislu razvoj srpskog književnog jezika nije zaključen $s$ takozvanom prvom generacijom utemeljitelja beogradskog stila, već naprotiv - nastavljen je dolaskom i izmjenjivanjem novih imena na književnoj sceni sve do današnjih dana.

Razvojem i prihvaćanjem beogradskog stila eliminirani su drugi potencijalni jezični modeli, što je među pojedinim piscima izazvalo otpor. Takva je bila reakcija najmlađe generacije modernista ,jer je njegova normativnost, preciznost i jasnost doživljavana kao svojevrsna brana individualnim pesničkim poetikama i eksperimentima sa jezikom" ${ }^{27}$. Tako su, primjerice, Petar Kočić i Stanislav Vinaver stvorili otklon prema jezičnoj folklornoj tradiciji, ali i prema novom književnom standardu. Vinaver je tek u poetskom jeziku avangardnih autora poput Miloša Crnjanskog, Rastka Petrovića ili Momčila Nastasijevića vidio novi duh materinskog jezika i njegovih mogućnosti. Ipak, kako ističe Vesna Matović, ${ }^{28}$ treba imati na umu da je jezik (tih) pisaca rezultat složenog evolutivnog, transformativnog procesa, kao i različitih otpora jezičnom standardu.

\section{JEZIČnE INOVACIJE I NJIHOVA KODIFIKACIJA}

Najznačajnije jezične promjene koje je donio beogradski stil dogodile su se na sintaktičkom planu. Prije svega, prelazak sa sintakse folklornog, govorenog jezika na sintaksu pisanog izlaganja rezultirao je restrukturiranjem složenih rečeničnih modela te općenito stabilizacijom i kodifikacijom sintaktičke strukture rečenice. Tako je, primjerice, stabilizirana pozicija 'atribut + imenica', neutralizirana je pozicija 'glagol nepotpunog značenja + infinitiv', proširen je fond čestica i drugih diskursnih elemenata tipičnih za pisani jezik, pro-

\footnotetext{
25 А. БЕлић, „БеограАски стик“, 196.

26 Р. Sкок, „О jezičnoj kulturi“, 6.

27 В. МАтовић, „Писци као творци српског књижевног језика“, 13.

28 Isto, 16.
} 
širen je proces nominalizacije i drugo. Nadalje, na ortografskom planu normiran je sustav interpunkcije, dok je na morfološkoj razini došlo do redukcije sustava glagolskih vremena te širenja funkcija preostalih članova sustava.

Razradom i razvojem pojedinih funkcionalnih stilova značajno je proširen leksički i frazeološki fond književnog jezika. Otvorenost internacionalizmima te leksičko posuđivanje iz stranih jezika (posebice francuskog, njemačkog i ruskog) omogućilo je stvaranje slobodnijeg, intelektualnijeg i kreativnijeg jezičnog izražavanja. Tako se jezik udaljio od svoje folklorne osnove i oplemenio pod utjecajem europske kulture. ${ }^{29}$

Isprva „napredak književnog jezika nije bio praćen odgovarajućom kodifikacijom, oličenom u rečnicima, gramatikama i drugim priručnicima koji bi tadašnje stanje opisali i normativno utvrdilii“"30. Međutim, s vremenom se i to postupno realizira Stevanovićevom normativno-deskriptivnom gramatikom Savremeni srpskohrvatski jezik I - II (1964., 1969.), aktualnim službenim pravopisima, rječnicima te drugim normativnim priručnicima objavljenim u drugoj polovini 20. stoljeća, čime je konačno zaključena faza njegove kodifikacije.

Osim promjena na jezičnom planu, tijekom prve polovine 20. stoljeća nastupili su i značajni pomaci na planu sociolingvističkog statusa beogradskog stila. Zahvaljujući sve prestižnijem socijalnom statusu, njegova se upotreba počinje širiti i na druge kulturne centre u Srbiji. Stabilizacijom, stjecanjem socijalno prestižnog statusa i autonomnosti u odnosu na supstrat taj urbani standard oblikovan u Beogradu u konačnici stječe temeljne odlike zrelog književnog jezika doraslog svim svojim funkcijama.

\section{Napomena umJesto ZaKLJUČKa}

U ovom je radu tek ugrubo prikazana složenost procesa punog sazrijevanja jednog književnog jezika. Fokus je bio usmjeren na pitanje kako se na temelju izabrane organske osnovice razvio suvremeni srpski književni jezik kakav danas poznajemo. U mnogočemu srodni (pred)standardizacijski procesi odvijali su se u Hrvatskoj tijekom 19. stoljeća:

Hrvatski jezik bio je u 19. stojeću razdvojen, neujednačen, s književnošću pisanom na štokavskom vrlo proširenom narječju, ali i na kajkavskom. [...] Još nema jedinstvene norme, još manje kodifikacije, a i grafija još nije jednaka [...]. Određene privremene teškoće nastaju u odabiranju pojedinih jezičnih tipova, te se tako javljaju različiti pogledi na književni jezik za zajedničku i jedinstvenu hrvatsku književnost i kulturu, različite filološke, lingvističke škole i pravci. ${ }^{31}$

Koncem 19. stoljeća razvojni procesi srpskog i hrvatskog književnojezičnog izraza dubinski se povezuju i međusobno prožimaju prevladavanjem „Vukove škole“ u Hrvatskoj. Bez obzira na to kako se iz današnje perspektive tumači i vrednuje takav slijed događaja, izolirano sagledavanje razvoja suvremenog srpskog i hrvatskog književnojezičnog izraza nije moguće - ne samo zbog zajedničke osnovice za daljnji razvoj književnog jezika, nego

\footnotetext{
А. Мимановит, Кратка историја српског књижевног језика, 135.

30 П. Ивић, Преглед историје српског језика, 136.

31 Zlatko Vince, Putovima hrvatskoga književnog jezika, Zagreb 2002., 643-644.
} 
i zbog intenzivne hrvatsko-srpske/srpsko-hrvatske kulturne i svake druge razmjene koja se odvijala tijekom 20. stoljeća, sve do današnjih dana. Zato valja istaknuti da je taj iznimno važan aspekt književnojezičnog razvoja do danas umnogome ostao nerasvijetljen - kako iz političkih, tako i iz metodoloških razloga. Stoga stručnjacima tek predstoji sustavno bavljenje tom problematikom. Kada je riječ o metodološkim poteškoćama, one se u najkraćem mogu prikazati u formi pitanja nagoviještenog u samom naslovu ovog rada: Kako opisati razvoj književnog jezika u fazama kada prestaje biti pod "nadležnošću“ pojedinaca (koji donose odluke o njemu, provode jezično planiranje, opisuju ga i normiraju) te postaje dijelom kolektivnog komunikacijskog i umjetničko-stvaralačkog iskustva?

\section{$\cos$}

\section{The DeVElopment of A LANGUAGE: FROM A LANGUAGE PLAN TO A CONTEMPORARY STANDARD}

An insight into Croatistic and Serbistic historical overviews of standard language development reveals a common interest in the $19^{\text {th }}$ century as a period of intense standardization. Some key decisions regarding the basic features of the language (the stages of selection and description) and the explicit norm (the stage of prescription) were indeed made in the $19^{\text {th }}$ century. However, the development of a language entails much more than the aforementioned three stages. A language is formally accepted, it spreads and develops, adjustments are made so it can perform the basic functions of a literary standard (especially in terms of stylistic stratification and lexical richness), it is cultivated, constantly re-evaluated and, if necessary, reconstructed. This paper focuses on a process which began when the agreed-upon, formally accepted language plan began coming to life and developing in the works of writers, publicists, scholars, translators and other cultural figures who worked mostly in urban centres like Belgrade, Novi Sad and Zagreb in the late $19^{\text {th }}$ and early $20^{\text {th }}$ centuries. At that time, key steps were made towards establishing a contemporary standard as an organism shaped in accordance with a pre-established plan by writers and their increasingly stratified, increasingly varied literary, journalistic, scholarly and other work. The paper focuses on Serbian writers of the first half of the $20^{\text {th }}$ century (especially Belgrade writers) and the literary and linguistic context in which they worked. It emphasizes the important role their work played in the development of a contemporary standard, while discussing the concept of the Belgrade style, which marked the defining period of the process of standardization. Finally, examples are provided of the linguistic innovations that were introduced by the Belgrade style, in comparison to the so-called Vukovian form of the language.

Key words: the history of language, the standard, standardization, Serbian, the Belgrade style, Croatian

\section{$\cos$}

\section{Literatura}

Амександар БЕцић, „Београдски стић“, Наш језик, 2/1934., br. 7, 193-200.

Gillian Brown i George Yule, Discourse Analysis, Cambridge 1988. 
ВАадо ЂукАновић, „Београдски стил - преломни период у развоју српског стандардног језика“, Наш језик, 30/1995., br. 1-5, 122-131.

Einar Haugen, Dialect, Language, Nation, London 1972.

Павле Ивит, Преглед историје српског језика, Сремски Карловци - Нови СаА 1988.

Весна МАтовић, „Писци као творци српског књижевног језика“, Зборник Творци српског къижевног језика (ур. Весна Матовић и Миодраг Матицки), Београд 2011., 9-18.

Александар МимАновић, Кратка историја српског књижевног језика, Београд 2006.

Фубомир НЕАић, „Српски књижевни језик“, Сабрана дела, Београд 1929., 245-249.

Новица ПЕтковић, „Језик, књижевност и култура“, Словенске пчеле у Грачаници, БеограА 2007., 29-40.

Milorad Radovanović, Sociolingvistika, Novi Sad 1986.

Исидора Секуиић, Језик и култура, Нови СаА 2003.

Petar Sкок, „О jezičnoj kulturi“, Jezik, 1/1952., br. 1-2, 3-10, 33-38.

Zlatko Vince, Putovima hrvatskoga književnog jezika, Zagreb 2002.

Zlatko VINCE, „Zaokret u hrvatskom književnom jeziku“, Croatica, 6/1975., br. 6, 131-159. 